\title{
Double-barrel wet colostomy after total pelvic exenteration
}

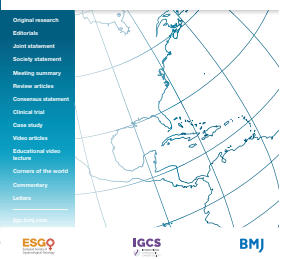

${ }^{1}$ Department of Gynaecologic Oncology, La Fe University and Polytechnic Hospital, Valencia, Spain

${ }^{2}$ Department of Urology, La Fe University and Polytechnic Hospital, Valencia, Valenciana, Spain

\section{Correspondence to} Dr Tiermes Marina, Gynaecologic Oncology, La Fe University and Polytechnic Hospital, Valencia 46026, Spain; tiermesm@gmail.com

Accepted 31 December 2019 Published Online First 19 February 2020

\section{Victor Lago, ${ }^{1}$ Tiermes Marina, ${ }^{1}$ Francisco Delgado Oliva, ${ }^{2}$ Pablo Padilla-Iserte, ${ }^{1}$ Luis Matute, ${ }^{1}$} Santiago Domingo ${ }^{1}$

Urinary and fecal diversion is needed to restore normal function after total pelvic exenteration because of gynecological cancer. ${ }^{1}$ In these patients, the Bricker procedure and end colostomy are often used for this purpose. Nevertheless, their use may lead to complications in patients with previous radiotherapy and may influence the ileum anastomosis. Additionally, the Bricker procedure has been reported to be associated a high rate of late complications (>30 days). Finally, two stoma are needed, conditioning the selfperception of the patient and increasing the difficulty of management of the stoma.

To avoid these drawbacks, double-barrel wet colostomy has been proposed as an alternative method to classical reservoirs using two stomas. ${ }^{2}$ If we compare the use of the Bricker procedure and end colostomy with double barrel wet colostomy, the latter presents the following advantages: it is technically easier, requires only one stoma, avoids small bowel anastomosis (previous radiation may predispose to leaks) and reduces surgical time. ${ }^{34}$ No differences have been reported in the rate of postoperative complications. ${ }^{2}$ Additionally, double-barrel wet colostomy is less complex for the patients regarding the stoma management and care, resulting in better selfperception by the patient.

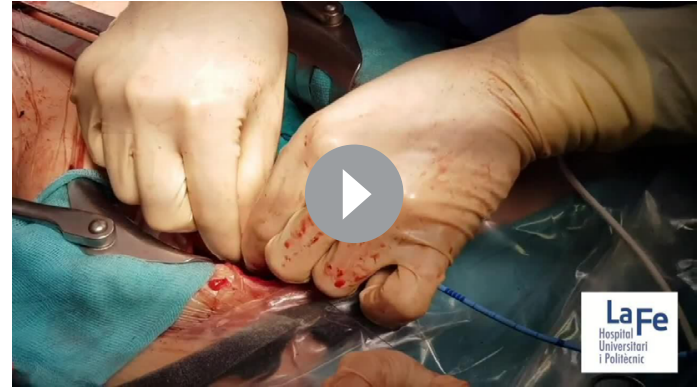

Video 1 Double-barreled wet colostomy: surgical technique.

Video 1 explains the step-by-step procedure in a patient diagnosed with relapsed cervical cancer previously treated with chemoradiotherapy plus brachytherapy.

During the postoperative period, several studies have demonstrated there is no statistically significant difference in the rate of postoperative complications such as stenosis of the uretero-intestinal anastomosis, obstructive nephropathy, formation of calculi in the conduit, urinary infections or electrolyte imbalances (Table 1). ${ }^{1-4}$ The urine drains into a reservoir distal to the stoma; consequently, the mixture of fecal content with urine and the resultant

Table 1 Advantages, complications and contraindications of ${ }^{1-4}$ double-barrel wet colostomy

\begin{tabular}{|c|c|c|c|}
\hline \multicolumn{4}{|l|}{ Modified double-barrel wet colostomy } \\
\hline \multirow[t]{2}{*}{ Advantages versus classical double diversion } & Main complications & & Contraindications \\
\hline & $\begin{array}{l}\text { General urinary } \\
\text { complications } \\
\text { (range \%) }\end{array}$ & $\begin{array}{l}\text { Specific urinary complications } \\
\text { (range \%) }\end{array}$ & \\
\hline Single stoma & $\begin{array}{l}\text { Pyelonephritis } \\
(0-13.4)\end{array}$ & $\begin{array}{l}\text { Anastomotic stenosis } \\
(0-11.1)\end{array}$ & $\begin{array}{l}\text { Insufficient colon } \\
\text { length }\end{array}$ \\
\hline Shorter operating time and length of stay & $\begin{array}{l}\text { Electrolyte abnormalities } \\
(0-33.3)\end{array}$ & $\begin{array}{l}\text { Anastomotic leak } \\
(0-18.6)\end{array}$ & $\begin{array}{l}\text { Insufficient ureteral } \\
\text { length }\end{array}$ \\
\hline $\begin{array}{l}\text { Formation of a separate urinary diversion in the } \\
\text { small bowel (frequently irradiated) is avoided }\end{array}$ & & $\begin{array}{l}\text { Urinary fistula } \\
(0-14)\end{array}$ & \\
\hline $\begin{array}{l}\text { Similar perioperative complication rates (mortality } \\
<30 \text { days, postoperative complications, re- } \\
\text { operations) }\end{array}$ & & $\begin{array}{l}\text { Risk of intestinal carcinoma origin at } \\
\text { the uretero-intestinal anastomotic site }\end{array}$ & \\
\hline \multicolumn{4}{|l|}{$\begin{array}{l}\text { Similar long-term complication rates (pyelonephritis, } \\
\text { electrolyte disturbances, urinary anastomotic } \\
\text { problems) }\end{array}$} \\
\hline Improved quality of life & & & \\
\hline
\end{tabular}

(C) IGCS and ESGO 2020. No commercial re-use. See rights and permissions. Published by BMJ.

To cite: Lago V, Marina T, Delgado Oliva F, et al. Int J Gynecol Cancer 2020;30:1650-1651. 
ascending pyelonephritis is greatly reduced. Furthermore, with adequate stoma care and regular change of collection appliances, peristomal dermatitis and other local skin complications can be avoided or easily controlled.

Regarding the management of the stoma and the quality of life of these patients, they are generally satisfied with the functional results. They should be reviewed regularly by a stoma therapist during the follow-up in order to solve any peristoma problems. An ileostomy bag with an air filter is used; urine draining is done by opening the clamp, and the pouch must be emptied when it's onethird full of stool. The most common complaint is the need to empty the collection bag during the night more frequently. On average, patients must change the collection system every 5 days.

Finally, one of the most important advantages is the improvement in the quality of life and self-perception of these women. Lopes de Queiroz used the QLQ-C30 questionnaire for measuring quality of life in five of nine patients who underwent double-barrel wet colostomy, and reported high functional results and global improvement in their health status.

Twitter Tiermes Marina @Tiermes
Contributors VL: Conceptualization, video editing, writing the original draft. TM: Conceptualization, video recording, writing the original draft. FD0: surgery. PP-I: Conceptualization, review of draft. LM: Conceptualization, review of draft. SD: Conceptualization, project administration, surgery and video recording, supervision, review of draft.

Funding The authors have not declared a specific grant for this research from any funding agency in the public, commercial or not-for-profit sectors.

Competing interests None declared.

Patient consent for publication Not required.

Provenance and peer review Not commissioned; externally peer reviewed.

\section{REFERENCES}

1 Lago V, Poveda I, Padilla-Iserte P, et al. Pelvic exenteration in gynecologic cancer: complications and oncological outcome. Gynecol Surg 2019;16:1.

2 Gan J, Hamid R. Literature review: Double-barrelled wet colostomy (one stoma) versus ileal conduit with colostomy (two stomas). Urol Int 2017;98:249-54.

3 Salgado-Cruz L, Espin-Basany E, Vallribera-Valls F, et al. Double barreled wet colostomy: initial experience and literature review. Scientific World Journal 2014;2014:1-7.

4 Gachabayov M, Lee H, Tulina I, et al. Double-barreled wet colostomy versus separate urinary and fecal diversion in patients undergoing total pelvic exenteration: a cohort meta-analysis. Surg Technol Int 2019;35:148-52. 